\title{
Interactive comment on "InSAR-based
} characterization of rock glacier movement in the Uinta Mountains, Utah, USA" by George Brencher et al.

George Brencher et al.

qbrencher@gmail.com

Received and published: 27 April 2021

Please see supplement file for responses to your comments.

Please also note the supplement to this comment:

https://tc.copernicus.org/preprints/tc-2020-274/tc-2020-274-AC3-supplement.pdf 